\title{
TRÁFICO DE DROGAS: UMA OPÇÃO ENTRE ESCOLHAS ESCASSAS
} TRAFFIC OF DRUGS: NA OPTION AMONG LIMITTED CHOICES

\author{
Ana Amélia Cypreste Faria e Vanessa de Andrade Barros \\ Universidade Federal de Minas Gerais, Belo Horizonte, Brasil
}

\section{RESUMO}

Este trabalho procura compreender os aspectos psicossociais que permeiam a adesão de pessoas ao tráfico de drogas em seu contexto histórico e econômico-social, por meio de pesquisa realizada no ambiente carcerário, onde foram recolhidas histórias de vida de pessoas envolvidas com o tráfico. Em um ambiente socioeconômico caracterizado pela precarização das relações de trabalho, pelo desemprego e pelo apelo consumista afinados com as premissas econômicas neoliberais tem-se uma situação de exclusão social e de cidadania. Assim, o tráfico se mostra como uma atividade econômica possibilitadora de inclusão, mesmo que marginal, na ordem capitalista. Uma opção a ser feita entre escolhas limitadas.

Palavras-chave: história de vida; tráfico de drogas; trabalho marginal.

\begin{abstract}
The present work has as its purpose to comprehend the historical, social and economic context and the psychosocial aspects that are related to the adhesion to the traffic of drugs. Through researches that have taken place at the prision environment, by listening to the life history of people envolved in the traffic, we tried to understand the relationship of this context to the individual choise. Characterized by precarious working conditions, unemployment and consumism seduction as a result of the new liberal economic, there has been a situation of social exclusion and a citizenship exclusion. There for, the traffic has been shown as an economical activity that allows the person to be included, even though in a marginal way, in the capitalism order. An option to be made among limited choices.
\end{abstract}

Keywords: life history; traffic of drugs; marginal work.

\section{Introdução}

Dowdney (2004) salienta que a adesão ao tráfico de drogas que, a princípio, pode ser entendida como uma "escolha voluntária", carrega em si uma opção, mas, conforme salienta, entre alternativas escassas.

A questão a ser problematizada neste artigo se refere à escassez de alternativas de escolha de modos de vida aos jovens que são aliciados pelo tráfico - cada vez mais precocemente - conforme constatação de nossa pesquisa. Buscamos compreender os aspectos psicossociais de suas trajetórias e como significam tais escolhas, levando-os à adesão a essa atividade ilegal. Entendemos que, apesar das limitações impostas pelo contexto social a que são submetidos, existem aspectos subjetivos que influenciam esse engajamento, configurando-se em fatores psicológicos marcados por certo grau de voluntariedade.

Isso porque, em nosso entendimento, o ser humano é um ser histórico, capaz de transformação cultural, social e política do meio em que vive, a partir das esco- lhas que norteiam sua vida pessoal e comunitária. Cada decisão tomada traz em si uma historicidade que a influencia, porém não a destitui de seu caráter de transformação e possibilidade de ressignificação histórica.

A realidade identificada por nós revela um quadro de expressivo aumento no número de pessoas aliciadas pelo tráfico de drogas, cujas atividades são submetidas a um processo de organização hierárquica, produtiva e comercial, com delimitação de mercado baseada na força e na violência entre grupos. À frente dessa organização, há líderes com acentuado poder de decisão e manutenção do controle da comunidade na qual fazem parte.

Conforme nos esclarece Carreteiro (2001, p. 164):

No que se refere às formas de sociabilidade locais que daí surgem podemos dizer que o "gerente da droga" tem, em certos aspectos, as mesmas características do chefe da horda mostrada por Freud (1912), em Totem e Tabu. Ele possui sobre os membros da comunidade um poder de vida ou morte.

Em face de tal realidade, procuramos apresentar, neste artigo, as análises realizadas quando de nossa 
pesquisa de mestrado sobre as condições econômicas e político-sociais a que são submetidas pessoas aliciadas pelo tráfico. Buscamos compreender as formas de sociabilidade criadas a partir desse contexto e seu impacto na vida da comunidade que convive diariamente com a clandestinidade do tráfico de drogas.

\section{Percurso metodológico}

Escolhemos como método principal de pesquisa o Recolhimento de História de Vida na perspectiva da Psicossociologia Clínica por nos proporcionar, por meio da escuta da narrativa de vida de um sujeito, informações sobre "os aspectos menos visíveis da vida social" (Cabanes, 2000), possibilitando o reconhecimento de um saber social na singularidade da história de vida do sujeito.

Como ressalta Enriquez: "É através da escuta do mais particular que poderemos apreender o mais geral, é debruçando-nos sobre os adventos da alteridade que poderemos compreender como o vínculo social se tece, se liga, se desliga e se rompe" (Gaulejac, 2001, p. 46).

O trabalho de campo foi realizado em uma unidade prisional da Associação de Proteção e Assistência ao Condenado - APAC, em um estado brasileiro, tendo se iniciado em março de 2007, com encontros semanais com o recuperando ${ }^{1}$, ficticiamente, chamado Paulo. Além do recolhimento desta história de vida, foram realizadas entrevistas em profundidade com outros recuperandos e com os familiares de Paulo, em sua residência e no Serviço de Psicologia Aplicada do Departamento de Psicologia da UFMG.

\section{Tráfico de drogas como uma escolha: história de vida de Paulo}

Ao falarmos do tráfico de drogas ilícitas como uma escolha entre opções escassas, estamos apontando para o caráter contraditório do discurso que prega a existência de condições iguais de vida entre os cidadãos. Nessa retórica diz-se que lhes são oferecidas as mesmas oportunidades de estudar, ter uma profissão e se sustentar, bem como à sua família, por meio de trabalhos considerados legais.

Assim, o tráfico de drogas, apesar de sua ilegalidade, torna-se uma opção entre poucas alternativas. As possibilidades de escolhas vão se restringindo à medida que os sujeitos não são preparados para o mercado de trabalho legal, cada vez mais competitivo e excludente. Desde cedo, participam de uma sociabilidade que idolatra, teme e protege o traficante de droga. São expostos a um meio social que aspira ao sucesso financeiro e ao consumismo que eles representam e, assim, admiram aqueles que conseguem atingi-lo, mesmo que de forma ilegal. Sem fazer frente às exigências do mercado neoliberal, e, assim sem condições de galgar o sucesso por ele determinado, vislumbram, nas atividades ilícitas do tráfico de drogas, uma alternativa de driblar o sistema excludente e, ao mesmo tempo, nele serem incluídos mesmo que marginalmente.

Neste ponto de nossa reflexão, é importante que façamos uma breve síntese da história de vida recolhida. Paulo, um cidadão brasileiro, conviveu desde criança com traficantes onde morava, em um bairro de uma cidade do interior do estado. Iniciou sua carreira no tráfico como aviãozinho ${ }^{2}$, fazendo pequenos favores aos traficantes, tais como, levar recados e esconder armas. Embora seu pai tenha tentado tirá-lo deste convívio mudando-se de bairro, Paulo continuou a estabelecer contatos com os traficantes do novo local de moradia, subindo rapidamente na hierarquia: vapor $^{3}$, olheiro ${ }^{4}$, gerente e dono de "bocas".

Até então, o bairro onde eu morava não tinha bandido. Em pouco tempo, foram chegando vários traficantes trazendo as drogas e armas. Quando tinha uns 13 anos um deles falou: "e ai menor, vai lá pegar um negócio pra mim" foi assim que comecei a ser aviãozinho $e$ depois olheiro e depois fui crescendo até me tornar o gerente da firma e o patrão, quando meu patrão morreu. Minha "boca" era muito grande, tinha uns 50 bandidos. Um bandido me chamavam de irmão porque eram amigo, entrou em contradição com o outro, um comprou a droga com o outro, não pagou a droga, o outro foi e matou ele, envolveu na guerra com outro, matou o outro, ai do avião que eu era, me transformei no vapor, já não era mais avião na já era avião que compra as coisas pro bandido, o bandido não pode andar, bandido trabalha escondido, ele é intocável ... nessa época aí meu pais brigava muito comigo me dava no coro, eu falava, pai, ta tranquilo, eu só entrego pra eles aí, ele falava que eles iam me pegar, me entregá. Um bandido matava o outro, vamos supor tem lá a guerra feia um ta querendo que o outro trafica o outro ta querendo meter o assalto ai aquele que furta é mais perigoso que o que vende droga, o que mete furto, assaltante, quer pegar o revólver, porque o revolver traz mais dinheiro ... o pessoal entrou em desentendimento com o outro, o traficante e o assaltante, o traficante quer ganhar o dinheiro tranquilo mas o assaltante quer buscar o tesouro, meter o revólver e pegar o tesouro... o que acabou em um matando o outro, ai o que aconteceu, acabou os criminosos de verdade, ai veio nós, né? Ai já era eu, é... eu já não era mais o avião, era o vapor e o vendedor também, eu mexia com entorpecente, né? Comecei a vender droga igual doido, só mexia com entorpecente, ganhava muito dinheiro. A violência aumentou muito, mataram o dono da minha "boca", como eu era seu braço direito, fiquei sendo o dono da "boca". Passei a ser o dono de tudo. Minha "boca" era famosa, muito 
perigosa. Ai ameaçaram de me matar. Queriam minha

"boca'. Chegou um pessoal de São Paulo. Eu comecei a ir para a Igreja, levando a arma. Fiquei com medo de ser morto. Uns caras aproximaram de mim e me deram uma facada no braço. Chegaram me chamando de amigo... e me esfaquearam. Meu pai falava... eu trouxe você para cá para você sair do crime e você entrou nele de novo (Paulo).

Sua formação escolar foi interrompida sem concluir o ensino fundamental. Paulo relatou que o tráfico lhe possibilitava acesso ao dinheiro, ao poder e ao reconhecimento. Mesmo tendo trabalhado legalmente, em alguns momentos de sua vida, em estabelecimentos comerciais e na construção civil, sempre se manteve no tráfico, simultaneamente. Foi preso ao se envolver em outras atividades ilegais, assaltos a bancos, a caminhões de carga e a supermercados, com o intuito de conseguir maior volume de dinheiro para investir em seu negócio.

\section{Para compreender 0 tráfico de drogas}

Três dimensões de análise são necessárias para nos ajudar a compreender o tráfico de drogas:

1. Sua relação com a economia neoliberal

2. A busca por reconhecimento

3. O funcionamento da organização

\section{O tráfico e a economia}

Pensar no tráfico de drogas como uma atividade expressiva no cenário mundial e notadamente brasileiro, que absorve grande quantidade de pessoas a despeito dos riscos de uma forma de sociabilidade marginal é dirigir nossos esforços para a compreensão das transformações pelas quais vem passando o mundo contemporâneo. Nas palavras de Feffermann (2006, p. 15):

Há outras formas de tratar o fenômeno do tráfico de drogas; todavia, existe um consenso de que se está diante de uma das indústrias mais lucrativas do mundo, ultrapassando até a petrolífera.

A globalidade, as grandes transformações tecnológicas e de organização aplicadas à produção induzem à expansão dessa indústria ilegal. ... Pode-se conceber que o mercado ilegal tem surgido como resposta à marginalidade econômica.

Do exposto, podemos constatar que, apesar de seu caráter ilegal, o tráfico participa da atividade geradora de capital, detendo um forte e organizado esquema de produção e mercantilização de drogas, configurando-se, hoje, uma prática atrativa, tanto pela possibilidade de acúmulo de capital, quanto pelo reconhecimento social que proporciona aos traficantes, numa forma de sociabilidade extremamente peculiar. O reconhecimen- to proporcionado pelo tráfico foi apontado em vários depoimentos de recuperandos:

Aqui na APAC eu não sou conhecido, lá na minha quebrada, todo mundo me conhece. A senhora sabe, né, bandido todo mundo conhece. A senhora viu aquela prisão que houve de traficantes e apareceu no jornal... é... eu estava nela, apareceu na TV, todo mundo viu... (Recuperandos).

Embora estejam entrelaçados numa relação de interdependência histórica e causalidade mútua, podemos buscar entender os aspectos que caracterizam este contexto econômico, político, jurídico e social estruturantes das condições fomentadores do tráfico de drogas. Nosso intuito é compreender as peculiaridades de cada contexto e, assim, poder analisar suas relações de influência que geram o complexo emaranhado da sociedade brasileira cada vez mais susceptível a esta atividade ilícita.

Economicamente, estamos situados em um mundo capitalista globalizado. O relevante, ao tentarmos entender a globalização, é que, enquanto fenômeno mundial, provoca uma bipolaridade em um nível intra e internacionais de excluídos e incluídos no mercado, na medida em que estabelece quais serão os indivíduos e grupos que possuem as características para se adaptarem aos mercados globais e quais não as possuem, estando, assim, numa posição de exclusão que poderá levá-los ao desamparo em relação aos seus direitos enquanto cidadãos.

Conforme nos ensina Véras:

no Brasil, políticas econômicas atuais, que poderiam chamar-se neoliberais, acabam por provocar, não políticas de exclusão e, sim, políticas de inclusão precária e marginal, ou seja, incluem pessoas nos ... processos econômicos, na produção e na circulação de bens e serviços estritamente em termos daquilo que é racionalmente conveniente e necessário a mais eficiente (e barata) reprodução do capital. (Véras, 2001, p. 39)

Tal contexto brasileiro ressaltado por Véras acarreta um cenário de desigualdades sociais cada vez mais acentuadas. Ademais, o mundo do trabalho desponta como alvo de práticas de precarização, revelando o mecanismo do capital de gerar mais lucro, com menos investimentos em melhoria de condições de trabalho, embora haja intensos esforços no sentido de melhorar tecnologicamente a competitividade da empresas.

Como salienta Antunes (2006, p. 15):

A crise experimentada pelo capital, bem como suas respostas, das quais o neoliberalismo e a reestrutuação produtiva da era da acumulação flexível são expressão, têm acarretado, entre tantas outras consequências, profundas mutações no interior do mundo do trabalho. Dentre elas podemos inicialmente mencionar o enorme desemprego estrutural, um crescente contingente de 
trabalhadores em condições precarizadas, além de uma degradação que se amplia, na relação metabólica entre homem e natureza, conduzida pela lógica societal voltada prioritariamente para a produção de mercadorias e para a valorização do capital.

Submetidos às condições precarizadas de trabalho e sem possibilidades de participação na roda viva do capital, estes trabalhadores ficam mais vulneráveis no que tange ao acesso aos meios de produção e inclusão global, mostrando-se pauperizados e desprotegidos frente ao argumento neoliberal de que sua exclusão se deve a sua despreparação para o mercado e de que é sua responsabilidade se tornar competente para as exigências desse mercado.

Dessa forma, o trabalho que poderia significar um atenuante para a crise do capital, oferecendo novas perspectivas emancipatórias, continua reproduzindo o poder do capital sobre si mesmo e se constituindo numa poderosa estrutura totalizante de organização e controle do metabolismo societal ${ }^{6}$.

A desigualdade econômica que o caracteriza acarreta a distância entre as classes sociais detentoras de condições globais de competitividade, daquelas excluídas do mecanismo econômico.

Por meio do tráfico, abre-se para os sujeitos a oportunidade de serem incluídos neste sistema capitalista que os excluíram economicamente, negando-lhes condições mínimas de sobrevivência, e/ou não lhes oferecendo possibilidades de fazer frente ao apelo consumista estimulado pelas políticas neoliberais.

O trabalho, legalmente considerado, constituiu-se numa atividade pouco compensatória, na medida em que não oferece condições para o acesso ao nível de vida desejado e idealizado como símbolo de sucesso e de valorização pessoal: "Pra que eu precisava trabalhar se o tráfico me dava todo o dinheiro, ele entrava por todos os lados?" (Paulo)

Ademais, o consumismo incentivado pela ordem econômica neoliberal cumpre seu papel ideológico:

Os movimentos da "globalização" produzem efeitos paradoxais, uma vez que as relações objetivas entram em contradição com os conteúdos das promessas liberais nas quais todos possuem as mesmas oportunidades de ascensão social e de consumo. Ocorre, então, a exclusão (ou inclusão marginal) de uma massa cada vez significante, de dimensão marcante nos intercâmbios simbólicos tal como estes se apresentam e são valorizados nas sociedades capitalistas. Quer dizer, o consumo possui dimensão simbólica com elevada significação social. (Feffermann, 2006, p. 31)

Diante do depoimento de um recuperando, podemos constatar a força do apelo consumista, justificando ações criminosas:
Minhas filhas queriam uma Barbie. Achei que custava pouco. Quando fui ver, era muito caro. Então eu pensei, é claro que vou ter que dar a Barbie pra elas. Elas não vão ficar sem a Barbie, não. Ai eu peguei a arma, fui pra pista, assaltei umas pessoas e consegui o dinheiro para comprar as Barbies pra elas. (Recuperando).

Eu só usava roupa de marca, não ia a uma festa se eu não tivesse com a melhor roupa e o melhor carro. (Traficante de drogas)

Eu comprava os melhores cremes exampus para minha mulher.. comprei uma casa, todos os eletrodomésticos.. uma moto, eu adoro motoca (Paulo).

Eu só uso roupa de marcas. A senhora sabe, bandido que é bandido só pode usar roupa de marca (Recuperando).

Contudo, a exclusão econômica intensificada pelas premissas do neoliberalismo, aí incluída a precarização das relações de trabalho, por si só, não seria capaz de explicar a elevada adesão das chamadas classes vulneráveis ao tráfico de drogas. Politicamente, temos um quadro que corrobora esta exclusão econômica, denominada exclusão de cidadania.

A exclusão da cidadania é entendida como o não-cumprimento por parte do Estado do que Dowdney (2004) salienta como contrato social, ou seja, a ausência do Estado em proporcionar aos cidadãos condições dignas de vida, saúde, educação e justiça, através de instituições públicas designadas para tal.

Assim caracterizado, o metabolismo social passa a ser regido por premissas e interesses econômicos, apresentando a flexibilização e precarização das relações de trabalho, desemprego estrutural e o apelo consumista que cria a ditadura do ter como sinônimo de sucesso e status.

Diante desse contexto, a ausência do Estado como agente social do bem-estar, enfatiza a desproteção social, levando à exclusão de cidadania. Tem-se um ambiente fértil para as atividades ilícitas que permitem a chamada inclusão perversa, pela via da marginalidade.

\section{Reconhecimento, fama e dinheiro}

Para Araújo (2001), a busca de reconhecimento revela dois aspectos dignos de atenção. $O$ primeiro se refere à finalidade última que se pode identificar no anseio pelo reconhecimento: a procura de apaziguamento, de consecução de uma obra perene. O segundo nos aponta para o projeto heroico que aqui nos interessa particularmente, pois pudemos identificar, nos depoimentos de Paulo, o orgulho que sentia diante do reconhecimento e respeito da comunidade diante do poder conferido pelo 
tráfico: "Eu sou o Paulo, é... todo mundo me respeitava. Eu era conhecido em todas as favelas de (... $)^{7}$ Todos me conheciam, eu entrava e falava: e ai meu irmão? Todos me cumprimentavam..." (Paulo).

Assim, se entendermos que a ilusão está presente na construção dos laços sociais balizando a busca de reconhecimento, podemos compreender o quanto o anseio heroico pode ter um lugar de destaque, pois é o herói que representa, de maneira bem clara, a luta entre o reconhecimento do desejo e o desejo de reconhecimento.

Para Araújo (2001), o heroísmo não está estritamente relacionado ao modo de vida "ego-centrado", há outras maneiras de buscar o reconhecimento através de opções de vida consideradas altruísta sendo mártir, revolucionário, protetor de uma comunidade. Para ele:

Nos dois casos, temos apenas que distinguir: existe um egoísmo que desconhece o outro (eu quero reconhecimento, dinheiro, poder ou bem-estar só para mim) e o egoísmo que convive com o altruísmo (se quero o bem estar para o outro, isso me renderá dividendos de reconhecimento (Araújo, 2001, p. 8).

Em nossa pesquisa, percebe-se que a figura do traficante é vista como um herói pela comunidade da qual faz parte, capaz de romper com situação de desigualdade econômica, enriquecer, assumir um papel de provedor e protetor, adquirindo respeito e admiração por parte dos seus pares, familiares e demais membros da coletividade.

Trata-se do fascínio exercido pelos chefes de "boca", por representarem um ideal a ser atingido, um sentimento amoroso. Contudo, este fascínio exercido pelo chefe de "boca" não está ligado a uma promessa de uma vida melhor em outro mundo, pois esta é feita pela religião.

Aqui na APAC eu não sou ninguém. Mas lá fora eu sou poderoso, eu sou o Paulo, bandido, dono de "boca". Quando eu cheguei na quebrada todos os irmão veio me cumprimentar: e aí irmão? Ta afim de umas paradas aí? Os irmãozinho de escopeta na mão falou: e ai irmão, você sabe que você é nosso patrão né? Eu disse: que isso irmão, eu não sou mais nada não, vocês aqui é que manda, vocês é que são o patrão. Eles disse: Que isso irmão você continua sendo nosso patrão, nosso irmão...Todos foram lá em casa, eles levaram mulher pra mim. Irmã, até tia mais velha. Eu disse, que isto irmão, não precisa me dar a sua tia não. Que isto irmão, você merece, pode escolher. É só falar que é bandido que chove de mulher em cima. (Paulo)

$\mathrm{O}$ fascínio diante de alguém capaz de lhes dar o que a vida não lhes pôde proporcionar: a inclusão em um mundo de conforto, de acesso ao mundo material, mas também a proximidade e o ser desejado por aquele que tem o poder. Não se trata de uma promessa de um mundo melhor num futuro, uma vida plena no reino dos céus, mas sim de um imediatismo, de uma vida boa e prazerosa agora.

Aliás, é claramente percebido na fala de Paulo que o importante é viver o aqui e agora. $\mathrm{O}$ futuro se lhe apresenta como o hoje.

Bandido tem vida curta. Eu não tenho um sonho não. Não sabia que minha irmã tinha um sonho... acho estranho... não sabia que ela queria ser fisioterapeuta. Eu acho que vou viver até uns 43 anos (Paulo).

O crime dá isso para nós: respeito, fama e dinheiro (Recuperando).

Eugène Enriquez aponta o processo de idealização como algo importante para a criação de vínculos sociais:

Um certo grau de idealização ou, dito de outra forma, de transformação da sociedade e de suas instituições em um objeto maravilhoso, único, sem mácula ...é indispensável à criação do vínculo social e à emergência do sujeito humano (Enriquez, 2007, p. 64).

O processo de idealização é, assim, constatado não só nas relações entre traficante e comunidade onde o ideal de proteção, poder e força é corporificado, mas também nas próprias atitudes daqueles que se aliciam ao tráfico, na medida em que assumem este ideal de sucesso ditado pela sociedade, expressando seu desejo de se tornar rico e poderoso. "Estava iludido com o crime, ganhava muito dinheiro" (Paulo).

Vários depoimentos demonstraram o quanto a comunidade valorizava a atividade dos traficantes, não só pelo suporte financeiro dado às suas famílias, mas também pela admiração de seu poder e capacidade de "ganhar e subir na vida", não se mostrando como algo vergonhoso ou indigno pela comunidade a ele relacionado. Tais depoimentos evidenciaram que algumas pessoas da comunidade conferiam grande respeito à capacidade dos traficantes, admirando-os. Paulo nos relata o quanto os bandidos são referência de "tratar bem". Disse que "eram criminosos tenebrosos, mas tratavam a gente muito bem. Eu nunca levei cocão de bandido, nunca fizeram covardia, nunca me deram um tiro". Em outro momento, Paulo reitera o bom tratamento dado pelos bandidos: "o dia inteiro... convivência com criminosos, eu era avião dos bandidos, só que os bandidos me tratavam muito bem...".

Além dos aspectos já sinalizados da reciprocidade forçada e da consideração dos traficantes como protetores, outros foram revelavam o orgulho por parte do traficante e de moradores da comunidade não ligados ao tráfico: "Com o Paulo preso, fica mais dificil ganhar a vida. Era um dinheiro que vinha do crime, eu sei, mas a senhora entende, me ajudava bastante. Agora eu não tenho dinheiro nem pra pegar ônibus" (Mãe de Paulo). 
Verificamos que fazer frente a este ideal passa a ser um fator imperioso, digno do princípio de prazer, pois quer ser realizado a qualquer preço, mesmo que este preço seja a própria vida. Mais que um objetivo de vida, passa a ser uma ilusão, que cega, dá onipotência e justifica qualquer comportamento que garanta sua realização: "Fui iludido pelo crime, quando eu sair da APAC eu não sei se vou largar o crime não,... quando chover de mulher em cima de mim, eu não sei não" (Paulo, IV Curso de Conhecimento e Aperfeiçoamento).

Contudo, é interessante percebermos que este reconhecimento é algo que deve ser usufruído e mantido com muita vigilância uma vez que poderá acabar a qualquer momento, quando se é preso ou morto e substituído por outro traficante que passará a comandar "sua boca".

Em função disso, do seu caráter extremamente passageiro, parece-nos pertinente nomeá-lo como um reconhecimento volátil.

A palavra volátil, conforme dicionário da língua portuguesa significa "o que evapora depressa." (Mattos, 2001, p. 734). Daí compreendermos quanto esforço é despendido no sentido de fazer com que este reconhecimento dure o máximo possível e o ressentimento advindo da sua perda:

Minha mulher fez pilantragem comigo, quando fui preso não queria me visitar, me traiu está com outro cara. Dizem que o cara trata ela mal. É, quando ela tava comigo eu comprava tudo de melhor, a melhor maquiagem, os melhores cremes exampus, agora ela não tem nada disso. ... Agora que ela ta tendo que dar o duro para ter as coisas. Bandido tem que ficar esperto, na atividade, pois sempre estão querendo tomar a "boca" dele... lá no morro tem umas nove "bocas", de vez em quando um dono briga com o outro e toma a "boca" que ta dando mais dinheiro (Paulo).

Sustentar uma posição de poder na hierarquia do tráfico, gozar dos privilégios e manter o reconhecimento de seus pares, seus adversários e da comunidade exigem um grande esforço pessoal e a construção de uma logística de proteção e manutenção dos espaços (materiais e simbólicos) conquistados. Assim, exercida na clandestinidade, com justiça própria, tal atividade gera outras práticas criminosas, levando, na maioria das vezes à morte aqueles que por ela optaram.

\section{Organização: a justiça feita pelas próprias mãos na ausência da Justiça}

O tráfico de drogas possui normas de conduta que são respeitadas como leis, que visam garantir o controle e poder sobre seus integrantes e sobre a comunidade a qual pertence o grupo de traficantes. Estas leis, sem nenhum respaldo do Poder Judiciário, são rigorosamente respeitadas e obedecidas por todos a elas submetidas. $\mathrm{O}$ conformismo a elas e a aceitação delas como necessárias e às vezes consideradas naturais, fazem com que sejam seguidas subservientemente, sem o questionamento de sua legalidade, mas pela imposição dos traficantes. A necessidade de lealdade ocasiona, em troca, inúmeros favores, sendo a segurança e proteção as principais garantias tendo em vista as condições violentas da comunidade onde vivem, numa situação denominada por Dowdney (2004) como "reciprocidade forçada":

as facções de drogas desenvolveram um sistema de "reciprocidade forçada" para servir às suas necessidades de defesa e às necessidades de "lei" e "ordem" da comunidade. A "reciprocidade forçada" é aplicada através de tática dupla: de apoio mútuo e de um sistema de violência punitiva em caso de desobediência. ... Não é a total ausência do poder público que capacita as facções a continuarem a dominar as favelas, mas sim a incapacidade do estado de cumprir sua parte do contrato social. (Dowdney, 2004, p. 42)

Neste espaço, onde faltam políticas públicas concebidas e executadas pelos órgãos estatais garantidores dos direitos de cidadania é que encontram respaldo e legitimidade as determinações das leis do tráfico.

A observância e temor às leis impostas pelo tráfico revelam a vulnerabilidade a que estas comunidades estão submetidas, convivendo diariamente com cenas que apregoam a justiça na lógica do tráfico, mas que sinalizam para a ausência de justiça nos termos do Estado Democrático de Direito.

Empiricamente, pudemos constatar a ausência da justiça nos termos do Estado democrático de direito nestes depoimentos de Paulo:

Paulo iniciou o atendimento falando da sua irmã mais nova, que estava de mal dele. Disse que ela havia se envolvido com um bandido que "caguetou" o pessoal da sua "boca" para os "home" e que eles meteram três tiros na "boca" dele. Ao ser perguntado pelo estado de saúde dele, disse que o tal bandido já tinha saído do hospital, mas que não conseguia falar $e$ estava meio abobalhado. "Minha irmã não tem jeito, eu sempre falei para ela não ficar com bandido, mas ela acabou ficando. Eu precisei falar pro pessoal da "boca" porque eles queriam matar ela também. "ê, irmão, sua irmã está metida com gente traíra”. Eu sei, mas pode deixar que perto de mim não tem gente traíra não. Se eu descobrir alguma coisa, matar ela eu não mato não, mas dou muita pancada, eu arregaço ela. Eu sei que ela não é caguete, não. Pode ficar tranquilo. Ai eu fui falar para minha irmã, chamei o namorado dela de verme, ela ficou de mal de mim. Mas eu prefiro ela brava e viva do que morta (Paulo).

É interessante salientar, neste ponto de nossa discussão, a distinção que Dowdney faz de "poder paralelo" dos traficantes, termo amplamente usado pela mídia ao se referir às leis do tráfico impostas pelos donos de "boca", 
de "poder simultâneo" que é o termo considerado por ele como apropriado à realidade do tráfico por que:

O controle das comunidades é um modo de assegurar-se uma base defensável de venda da droga no varejo para alcançar esse objetivo de lucro ... Esse controle não resultou da capacidade das facções de suplantar o estado do ponto de vista político, social ou militar. Elas apenas ocuparam um espaço que o poder público não conseguiu ocupar. Por essas razões, as facções da droga não podem ser vistas como um estado ou poder paralelo, que seja alguma ameaça à manutenção do governo ou do estado. Como o controle que exercem se deve à incapacidade do governo de estar plenamente presente na favela, as facções devem ser vistas como "poder simultâneo" em relação ao controle sociopolítico das populações faveladas, mais do que como "poder paralelo" em oposição ao estado. (Dowdney, 2004, p. 55)

Através do pacto da "reciprocidade forçada", referida por Dowdney, as leis previstas pelo Código Penal Brasileiro são consideradas apenas como algo a serem dribladas, estrategicamente, com ações de proteção aos infratores para que não sejam cumpridas. A proteção dada a eles vai desde o silêncio da comunidade, que não denuncia as atividades ilícitas e nem quem as pratica, o auxílio à camuflagem das ações ilícitas até mesmo a ajuda em caso de perigo de prisão como oferecimento de esconderijos pessoais, de armas e dos produtos produzidos e vendidos pelos traficantes. Por outro lado, pudemos constatar o uso desta lei nos momentos em que se revela conveniente para os traficantes em situações tais como: uso de crianças para despistar as batidas policiais, escondendo armas para os traficantes ou drogas e na manipulação das evidências de crime, uma vez que as leis penais para infratores menores são menos rígidas.

Quando eu era pequeno, o pessoal lá do bairro juntava todo mundo pra fazer o time (... ${ }^{8}$ Eu ia no meio deles. Eu ficava nos meio dos bandidos. No (...) ${ }^{9} j a ́$ fui detido com oito armas. Eu levava e buscava droga. Fazia tudo por eles. Eu era de menor e não podia ser preso. Eu tenho $12 \mathrm{BOs}^{10}$ de posse ilegal de arma quando eu era de menor. $E 3$ BOs quando eu já era de maior. $O$ doutor fala pra gente falar tudo o que sabe, mas eu não falo de bandido não. Bandido é gente ruim, não tem sentimento. Policial tem número e tem que pagar se ele matar. Bandido mata e fica por isso mesmo... mas vi muita gente matando muita gente, sô, às vezes eu não podia falar o que sabe, não, né, eu tinha familia, quem tem família não pode falar o que sabe, né? Nesta descida, um cara da quebrada roubou droga... o outro sacou a arma e ia matar na minha frente. Eu falei, espera, irmão, ele vacilou... mas... o cara falou: "o que Paulo, você não quer que eu mate o verme, não? Eu disse, na minha frente não ... no outro dia o cara que roubou foi na minha casa agradecer. Eu disse que era pra ele tomar jeito, pois o crime não perdoa, não.
Todo fim de semana tem guerra lá na minha faç̧ão. Eles matam mesmo... Ninguém desobedece eles não. Eu falei pra minha mãe: se a senhora desobedece eles e eles pegarem a senhora, eu não vou atrás deles não. Eles são bandidos, eles é que mandam na rua, na "boca", tem que fazer o que eles mandam... (Paulo)

As leis do tráfico têm na vingança uma das suas premissas mais fortes e temidas. Como foi apontado em depoimentos dos recuperandos: "o crime não perdoa, se mandou matar e eu não matar, eles me matam."

De acordo com Lacerda (2008, p. 139):

As sociedades antigas, que não dispunham de um sistema judiciário como o nosso, costumavam se valer, com frequência, da vingança de sangue. ... Entende-se assim, o papel da vingança: quando em uma sociedade falta um aparelho judiciário adequado, ela aparece como o único recurso à mão, o que pode nos ajudar a compreender a vingança na lógica do trafico.

Como já ressaltamos anteriormente, a exclusão de cidadania a que estão submetidas às comunidades envolvidas com esta atividade ilícita não lhes permite o acesso à justiça, direito proporcionado pelo sistema judiciário. Dessa maneira, a justiça de que se valem os donos de "boca" para manterem o controle da comunidade, garantir a "reciprocidade forçada" e fazer valer as regras comerciais do tráfico tem na vingança uma forte base estruturante.

Quando foi indiciado por outro homicídio, Paulo teve o comportamento de ameaçar as possíveis testemunhas com vinganças caso depusessem contra ele:

Na minha saída, eu fui na casa das irmãs e mãe dele. Eu disse que era pra eles me livrarem disso tudo pois eu não iria assumir isto não... o outro que está acusado também está pressionando, a irmã disse que eu vi matar, então eu era culpado. Eu disse que se eles me acusassem, eu iria matar todo mundo, por fogo no barracão, não queria nem saber se tinha criança ou não. Eles disseram que vão livrar a minha cara. Eu não tenho coragem de fazer nada contra criança, não. Mas o outro irmão é ruim (Paulo).

Fica evidenciado, nesta fala de Paulo, o poder da ameaça da vingança para se obter os propósitos que se queira alcançar. Uma vez feita a vingança, Lacerda ressalta que: "Ele matou o patrão, ai não tem jeito não, tem que morrer. A lei de bandido é esta mesmo..." (Paulo)

Face ao sangue derramado, a única vingança satisfatória é o derramamento do sangue do criminoso. Não há diferença nítida entre o ato que a vingança pune e a própria vingança. Ela é concebida como uma represália, e cada represália invoca uma outra. Muito raramente o crime punido pela vingança é visto como o primeiro: ele é considerado como a vingança de um crime mais original. A vingança constitui, portanto, um processo infinito, interminável. (Lacerda, 2008, p. 141) 
Outro aspecto, evidenciado por nós, constata o quanto a lei do tráfico é aplicada não se importando o tempo que demore em que aconteça. Um recuperando que fora atendido por nossa equipe, foi executado após ter cumprido pena e ser colocado em liberdade. $\mathrm{O}$ peculiar desse fato é que foi assassinado devido às infrações à lei do tráfico anteriores à sua prisão, sendo que a morte não aconteceu logo após a sua saída. Tivemos informação de que um deles estava já se sentindo "de boa", ou seja, de bem com toda a comunidade, tranquilo, participando inclusive da vida social local. Foi executado a caminho de uma pizzaria com a família. "O outro problema da vingança é que ela não obedece a nenhuma proporcionalidade. Quem vinga uma morte nem sempre se contenta com apenas outra morte. Muitas vezes, são necessárias várias mortes para que se satisfaça o apetite de vingança" (Lacerda, 2008, p. 141).

Em vários depoimentos citados anteriormente, esta desproporcionalidade da vingança ficou bem nítida. Muitas vezes um roubo de uma parte da droga ou a não prestação de contas feita de maneira correta pelo vapor, pode levar à sua morte.

Importante notar que a vingança parece já ter se tornado parte da cultura do tráfico de drogas. Tornou-se natural, banalizou-se, já é esperada, conforme relato de outro recuperando, também dono de "boca":

eu tinha um amigo, meu irmão mesmo. Quando desci ${ }^{l l}$ em 23 de dezembro, encontrei com ele, combinamos muita coisa, ele ficou de passar na minha casa no dia seguinte. Dia 24 ele passou lá, eu tava tomando banho, ele esperou, conversamos, ficamos de encontrar no churrasco dia 25 e foi embora. Logo depois chegou a noticia que tinham matado ele. Chorei muito, fiquei com muita raiva e pensei logo em pegar quem tinha matado ele, mas depois pensei e resolvi não fazer nada, mas fiquei com medo porque todo mundo esperava que eu vingasse ele, era meu amigo, então eles podiam vim me matar primeiro antes que eu matasse eles. (Recuperando)

O âmbito de alcance da vingança poderá extrapolar o intramuros da prisão, em casos em que a testemunha em júris populares de assassinatos cometidos por traficantes, podendo acarretar a extensão do tempo de cumprimento da pena do condenado, é ameaçada ou mesmo tem toda sua família assassinada, por pessoas fora da prisão.

\section{Considerações finais}

A título de considerações finais, gostaríamos de salientar alguns dilemas com os quais nos defrontamos na realidade empírica e que possibilitam inúmeras reflexões e desafios científicos de interesse da psicologia social na sua interface com a psicologia do trabalho.
Pudemos constatar que, para aqueles envolvidos com o tráfico, apesar de cientes da ilegalidade da atividade, o seu exercício é considerado um trabalho. Embora, a princípio, apontem para certa dicotomia entre bandido e trabalhador, após o estabelecimento de confiança, relatam o orgulho que sentem do tráfico pelo seu nível de dificuldade e pelo que conseguem obter em termos financeiros, além do reconhecimento dado pela comunidade, conforme já vimos. "O tráfico é um trabalho, um trabalho muito perigoso. A senhora acha que é fácil ter que vender, manter a "boca" e ainda ter que fugir dos homi? Não é pra qualquer um, não" (Paulo).

Além desses aspectos, há que se ressaltar, também, a forma como produzem, compram, vendem matéria prima e drogas, bem como a maneira como se organizam hierarquicamente, administrando o negócio de modo que muito se assemelha à gestão de muitas empresas legalmente posicionadas, salvo peculiaridades sobre a violência apresentada neste artigo.

Do exposto acima, pareceu-nos pertinente finalizarmos nossa exposição, propondo um espaço de reflexão sobre a significação do trabalho na realidade de uma atividade marginal como o tráfico. É mister que tenhamos uma postura questionadora diante de aspectos que afrontam a concepção que atribui ao trabalho uma dimensão moral e deste modo, reconhecida pela sociedade como um todo. Embora ilegal, pudemos constatar que, pelo grupo social com ele envolvido, numa perspectiva de poder usufruir de melhores condições de vida e inclusão no que é posto como sinônimo de sucesso pela sociedade, ao tráfico é atribuída uma valoração social e econômica que lhe confere uma importância peculiar a esta camada da população.

Não cabe a nós, pesquisadores, julgarmos tal significação, mas mostrar, na sua concretude, sua existência, como um ponto inicial de reflexão sobre uma forma de trabalho marginal da sociedade mineira e brasileira que, a despeito de todo esforço de torná-la invisível, banindo socialmente os que a ela se aliciam, configura-se numa realidade social posta, sobre a qual não podemos nos calar.

\section{Notas}

1 Maneira pela qual os apenados que cumprem pena nas APAC's são identificados.

2 “Avião" termo utilizado para designar aquele que se encarrega de fazer as tarefas solicitadas pelo gerente ou dono de boca desde levar algum recado até entregar drogas para os vendedores na boca.

3 A palavra "vapor" é utilizada para caracterizar aquele que: "Vende droga diretamente aos clientes na boca de fumo e responde diretamente ao gerente de boca." (Dowdney, 2004, p. 54).

4 O "Olheiro" exerce a vigilância e proteção da boca de inserções da polícia ou invasão de facções rivais. Cabe a ele 
comunicar rapidamente, através de códigos combinados quando há batida policial na comunidade. Podem também usar fogos e, assim, são chamados de fogueteiros.

5 Dono de boca e Gerente de boca: "Função superior, autônoma... Responsável pela compra da cocaína e da maconha que será vendida na favela por meio de contato com um matuto, pelo fornecimento de armas aos empregados com base na comunidade, pelo relacionamento com outros donos, ... pelo pagamento de suborno à polícia... Também é chamado de o cara, o patrão, o homem, o cabeça, o amigo." (Dowdney, 2004, p. 57) Gerente de boca é responsável pela organização geral das operações diárias da venda da droga, relaciona-se diretamente com o dono. Pode também ser chamado de: braço direito.

6 Expressão cara a Antunes, que nos esclarece: "é, segundo Mészáros, o resultado de um processo historicamente constituido, onde prevalece a divisão social hierárquica que subsume o trabalho ao capital. Os seres sociais tornaram-se mediados entre si e combinados dentro de uma totalidade social estruturada, mediante um sistema de produção e intercâmbio estabelecido." (Mészáros, 1995, citado por Antunes, 2006, p. 19).

7 O nome das favelas citado por Paulo foi omitido aqui para garantir o sigilo das informações.

8 Omitimos o nome do time de futebol, ressaltado por Paulo em sua fala, por razões de sigilo.

9 Pela mesma razão anterior, excluímos deste artigo o nome do estádio de futebol presente na fala de Paulo para mantermos o sigilo.

10 "BO" - Sigla usada para designar Boletim de Ocorrência Policial.

11 "Descida" é o termo usado pelos apenados para designar as saídas temporárias autorizadas pela justiça.

\section{Referências}

Antunes, R. (2006). Os sentidos do trabalho - Ensaio sobre a afirmação e a negação do trabalho. São Paulo: Boitempo Empresarial.

Araújo, J. N. G. (2001). O Desejo e o Outro - A dialética do reconhecimento em Hegel. Belo Horizonte: Departamento de Psicologia da PUC-MG.

Cabanes, R. (2000). Quelle approche biographique? Revue Internationale de Psychosociologie - Récits de vie et histoire sociale, 14, 1-5.

Carreteiro, T. C. (2001). Perspectivas da cidadania brasileira: entre as lógicas do direito, do favor e da violência. In J. N. G. Araújo \& T. C. Carreteiro (Orgs), Cenários sociais e abordagem clínica (pp. 154-168). São Paulo: Escuta; Belo
Horizonte: Fumec.

Dowdney, L. (2004). Crianças do tráfico-um estudo de caso de crianças em violência armada organizada no Rio de Janeiro. Rio de Janeiro: 7 Letras.

Enriquez, E. (2007). As figuras do poder. São Paulo: Via Lettera Editora e Livraria.

Feffermann, M. (2006). Vidas arriscadas: o cotidiano dos jovens trabalhadores do tráfico. Petrópolis, RJ: Vozes.

Gaulejac, V. (2001). Psicossociologia e sociologia clínica. In J. N. G. Araújo \& T. C. Carreteiro (Orgs.), Cenários sociais e abordagem clínica (pp. 35-48). São Paulo: Escuta; Belo Horizonte: Fumec.

Lacerda, B. A. (2008). A vingança e a justiça. In A. P. M. Júnior \& F. M. Pinto (Coord.), Execução penal - constatações, críticas, alternativas e utopias (pp. 139-148). Curitiba: Juruá Editora. Mattos, G. (2001). Dicionário Júnior. São Paulo, SP: FTD.

Véras, M. P. B. (2001). Exclusão social-um problema de 500 anos. In B. Sawaia (Org.), As artimanhas da exclusão - análise psicossocial e ética da desigualdade social. Petrópolis, RJ: Vozes.

Recebido em: 23/10/2009

$1^{\text {a }}$ Revisão em: 23/02/2010

$2^{\text {a }}$ Revisão em: 14/06/2010

Aceito em: 13/08/2010

Ana Amélia Cypreste Faria é Mestre pela Universidade Federal de Minas Gerais - UFMG. É analista de Políticas Públicas e Psicóloga da Prefeitura Municipal de Belo Horizonte. Endereço: Rua Universo, 260/302 - Santa Lúcia.

Belo Horizonte, Minas Gerais, Brasil. CEP 30350-480.

Email: amefaria@hotmail.com

Vanessa de Andrade Barros é Professora do Departamento de Psicologia da Faculdade de Filosofia e Ciências Humanas - FAFICH da Universidade Federal de Minas Gerais - UFMG. Mestre em Administração pela Universidade Federal de Minas Gerais (1992), doutora em Sociologia - Universite de Paris VII (1998) e pósdoutora na Conservatoire National des Arts et Métiers-Fr. Endereço: Avenida Antônio Carlos, 6.627. CEP 31270-901

Belo Horizonte/MG, Brasil. Email: Vanessa.abarros@gmail.com

\section{Como citar:}

Faria, A. A. C. \& Barros, V. A. (2001). Tráfico de drogas: uma opção entre escolhas escassas. Psicologia \& Sociedade, 23(3), 536-544. 